\title{
RESEARCH OF QUALITY AND SAFETY INDICATORS OF ORGANIC RAW MATERIALS FOR DEVELOPMENT OF NEW COOKIE RECIPES
}

\author{
Alina Tkachenko \\ PhD, Associate Professor ${ }^{l}$ \\ alina_biaf@ukr.net \\ Ivan Syrokhman \\ Doctor of technical sciences, professor \\ Department of Commodity Science, Technologies and Food Quality Management \\ Lviv University of Trade and Economics \\ 10 T.-Baranovskoho str., Lviv, Ukraine, 79005 \\ syrokhman@ukr.net \\ Lyudmyla Guba \\ PhD, Associate Professor ${ }^{l}$ \\ lyudmika@gmail.com \\ Yulia Basova \\ PhD, Associate Professor ${ }^{2}$ \\ basovay5@gmail.com \\ Elena Goryachova \\ PhD, Associate Professor ${ }^{2}$ \\ goryachova0ea@gmail.com \\ ${ }^{1}$ Department of Commodity research of foodstuffs ${ }^{3}$ \\ ${ }^{2}$ Department of Commodity research, biotechnology, examination and customs ${ }^{3}$ \\ ${ }^{3}$ Poltava University of Economics and Trade \\ 3 Kovalia str., Poltava, Ukraine, 36014
}

\begin{abstract}
Studies of quality and safety of organic flour and oils for the development of cookies are considered. The objects of the study are samples of organic spelt, corn and coconut flour; and samples of organic oils (camelina and hemp). The purpose of the study is to substantiate the feasibility of using organic raw materials for the development of new cookie recipes. To determine the quality and safety of organic flour, the nutritional value, physicochemical parameters and safety indicators (content of salts of heavy metals) have been analyzed. To determine the quality of organic oils, the fatty acid composition has been analyzed. Standard methods have been used for the study. The moisture content of the flour has been determined by the drying method. Ash content - by the method of organic matter charring. Atomic absorption and flameless atomic absorption methods have been used to determine the safety indicators of the flour. The fatty acid composition of oils has been determined by gas chromatography. It has been proved, that organic raw materials meet the safety requirements of the Regulation of maximum levels of certain contaminants in food, approved by the Order of the Ministry of Health of Ukraine № 368 of 13.05 .2013 and can be used as a promising enrichment for the nutritional value of cookies.
\end{abstract}

Keywords: organic cookies, organic raw materials, coconut flour, spelt flour, camelina oil, hemp oil.

DOI: $10.21303 / 2504-5695.2021 .001882$

\section{Introduction}

Excessive use of synthetic chemicals that pollute the environment, as well as mechanical disturbances of the soil and irrigation have led to negative consequences. These include the generation of resistant insects, fungi, weeds, the accumulation of chemicals in crops and soil, water and 
air pollution. All this contributes to some extent to the greenhouse effect and global warming [1]. Just that is why in many countries, such as the United States, Germany, Italy, Greece, France, Poland and a number of others, programs and legislative initiatives have been adopted to stimulate organic production. The EU has developed and is implementing an action plan for the introduction and expansion of organic production, most EU member states have their own national programs for the development of this area of agricultural activity [2]. The main forms of support for organic agriculture in the EU are grants for rural development programs, legal protection of producers, national action plans. Stimulating the development of organic agriculture in the world has led to an increase in organic production [3]. Thus, according to official data, in 2018 there were 71.5 million hectares of organic land in the world. The largest number of them is recorded in Oceania (36 million hectares), the European Union (15 million hectares) and Latin America (8 million hectares) [4]. In addition, consumers themselves note that they are increasingly choosing organic products. The above data indicate the relevance of the study of organic raw materials as a promising component of finished food products. In particular, the issue of developing flour products based on organic raw materials is poorly studied.

Flour products are quite popular among the population and are an integral part of the diet. The works of authors $[5,6]$ are devoted to the improvement of recipes and the search for new types of cookies. There are data on organic cookies, which include:

- spelt flour;

- rice molasses;

- butter;

- banana powder;

- sodium bicarbonate baking powder;

- vitamin B1.

Recipes for cookies based on organic raw materials are also known:

- whole-wheat flour;

- unrefined cane sugar;

- non-hydrogenated vegetable oils;

- rice flour;

- eggs;

- skimmed milk powder [7].

However, the assortment of organic raw materials is expanding every year. This encourages the search for new recipes using organic raw materials. Based on this, the purpose of the study is to substantiate the feasibility of using organic raw materials for the production of new types of cookies.

\section{Materials and Methods}

The objects of the study are samples of organic spelt, corn and coconut flour (Fig. 1) produced by the company «Organic Original» TM «Ecocord» (Ukraine); and samples of organic oils (camelina and hemp). Detailed characteristics of the samples are described in source [8].

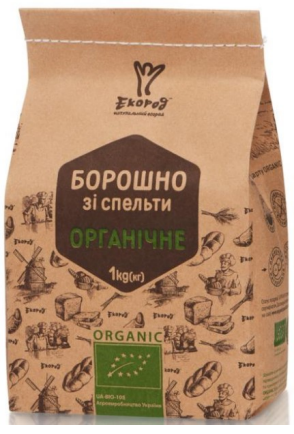

$a$

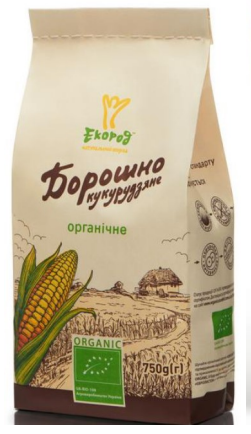

$b$

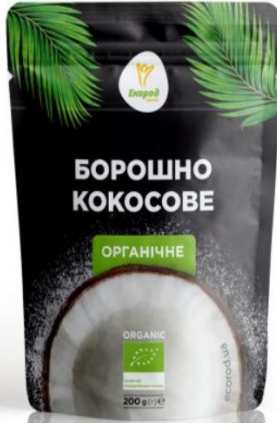

$c$

Fig. 1. Visual image of the objects of study: $a$ - organic spelt flour; $b$ - organic corn flour; $c$ - organic coconut flour 
The determination of the moisture and gluten content in the flour was performed according to standard methods. Studies of the baking properties of the flour were performed using a direct method, ie quality assessment by trial baking, which [9] provides a steamless method of preparing dough from flour, water, baker pressed yeast and salt.

The nutritional value was determined from the information on the package.

The moisture content of the flour was determined by drying $10 \mathrm{~g}$ of flour, ground in a mill, in an electric semi-automatic oven at $130^{\circ} \mathrm{C}$ for 40 minutes

The ash content was determined by the method of organic matter charring with low heating in a muffle furnace.

To study the content of toxic elements in new products, there were used conventional methods: copper, zinc, lead and cadmium were determined by the atomic absorption method, arsenic by the colorimetric method, mercury - by the flameless atomic absorption method.

The fatty acid composition of oils was determined by gas chromatography on a gas chromatograph HP 6890 (USA) Fig. 2.

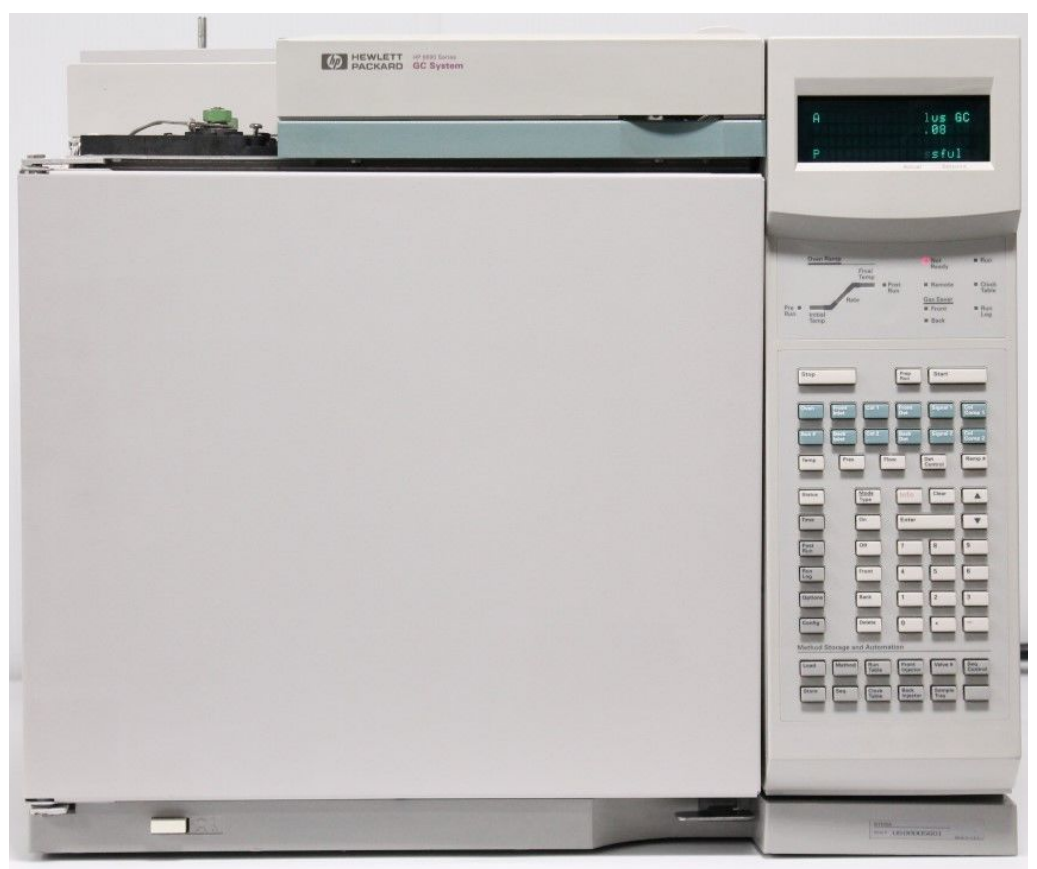

Fig. 2. Gas chromatograph HP 6890

\section{Results}

Coconut flour, corn flour and organic spelt flour were chosen to develop the recipes for the new cookies. There are data on the prospects of using coconut flour as a functional additive. Clinical studies have proven the usefulness of coconut flour to lower blood cholesterol [10]. Increased attention to semiwild varieties of wheat, namely spelt (Triticum spelta) is due to a number of reasons, among which we can highlight its suitability for low-cost agriculture, as well as some food and technological properties.

The nutritional and energy value according to the information on the label is given in Table 1.

\section{Table 1}

The nutritional and energy value of the flour

\begin{tabular}{|c|c|c|c|c|}
\hline \multirow{2}{*}{ Sample } & \multicolumn{4}{|c|}{ Content, g/100 g } \\
\hline & fats & proteins & carbohydrates & Energetic value (kJ) \\
\hline Spelt organic flour & 2.7 & 11.3 & 72.5 & 1429 \\
\hline Corn organic flour & 1.5 & 7.2 & 70.9 & 1381 \\
\hline Coconut organic flour & 26.6 & 14.7 & 17.0 & 1772 \\
\hline
\end{tabular}


As can be seen from Table 1, coconut flour has a high fat content and low carbohydrate content. At the same time, coconut and spelt flour have a high protein content -14.7 and $11.3 \mathrm{~g} / 100 \mathrm{~g}$, respectively. The introduction of these flour samples in the cookie recipe can significantly enrich its amino acid composition.

Table 2 shows the results of the study of flour quality indicators.

Table 2

The results of the study of flour quality indicators

\begin{tabular}{cccc}
\hline Indicator, $\%$ & Spelt organic flour & Corn organic flour & Coconut organic flour \\
\hline Moisture content & 10.5 & 11.7 & 12.8 \\
Ash content & 1.3 & 1.2 & 0.75 \\
Gluten content & 32.0 & 29.0 & 0.00
\end{tabular}

These physico-chemical parameters are within normal limits. The highest moisture content is recorded in coconut flour, the lowest - in spelt flour. In terms of ash content, corn and spelt flour are almost identical. Coconut flour has the lowest gluten content.

As the object of research is organic raw materials, an important step is the study of safety indicators. In particular - the content of toxic elements, because just contaminated soils and agrochemicals can be a source of their accumulation in raw materials. Table 3 shows the content of toxic elements in the flour.

Table 3

The content of toxic elements in the flour

\begin{tabular}{ccccc}
\hline Toxic element name & $\begin{array}{c}\text { Permissible level, } \\
\mathbf{m g} / \mathbf{k g} \text {, no more }\end{array}$ & Spelt organic flour & Corn organic flour & Coconut organic flour \\
\hline Lead & 0.5 & 0.24 & 0.31 & 0.30 \\
Cadmium & 0.1 & 0.04 & 0.05 & 0.06 \\
Arsenic & 0.3 & 0.1 & 0.1 & 0.26 \\
Mercury & 0.02 & $<0,001$ & $<0,001$ & $<0,001$ \\
Copper & 10.00 & 9.1 & 9.3 & 9.4
\end{tabular}

As can be seen from table 3, the content of safety indicators of the flour meets the normative ones. In particular, the lead content in all samples is almost twice less than the norm. The mercury content is almost invisible in all flour samples. The content of arsenic is the lowest in corn and spelt flour - only $0.1 \mathrm{mg} / \mathrm{kg}$, while the permissible level is $0.3 \mathrm{mg} / \mathrm{kg}$.

Since an important component of cookies is the fat base, the fatty acid composition of oils was studied. The results are shown in Table 4.

Table 4

The fatty acid composition of organic oils

\begin{tabular}{ccc}
\hline Fatty acid name & Camelina oil & Hemp oil \\
\hline Palmitic $_{(\mathrm{Cl} 6: 0)}$ & 5.78 & 9.9 \\
Stearic $_{(\mathrm{C} 18: 0)}$ & 2.45 & 6.15 \\
Palmitoleic $_{(\mathrm{Cl} 16: 1)}$ & 0.16 & 0.23 \\
Oleic $_{(\mathrm{C18:1)}}$ & 15.7 & 16.7 \\
Linoleic $_{(\mathrm{Cl} 8: 2)}$ & 49.2 & 61.2 \\
Linolenic $_{(\mathrm{C} 18: 3)}$ & 11.59 & 15.4
\end{tabular}

The results in Table 4 indicate a balanced fatty acid composition of vegetable oils. Their introduction into the recipe of products can affect the biological value of the lipid basis of cookies, enriching it with essential fatty acids. However, the comparison of the obtained results with [10] does not give grounds to believe that organic oils are superior to traditional ones in fatty acid composition. 


\section{Conclusions}

The proposed samples of organic corn, coconut and spelt flour are of high nutritional value. In particular, coconut and spelt flour are characterized by the high protein content -14.7 and $11.3 \mathrm{~g} / 100 \mathrm{~g}$, respectively. That is why the samples should be considered promising in terms of enrichment of the protein composition of finished products. The moisture, ash and gluten content have been determined in the products. Coconut flour does not contain gluten. It can be used in recipes of gluten-free products. According to the content of toxic elements, all flour samples meet the standards. Samples of organic oils - camelina and hemp - have been also studied. Vegetable oils are a promising source of essential acids, which is why the fatty acid composition has been studied. It has been found, that the studied oils contain a significant amount of poly- and monounsaturated fatty acids, in particular palmitic, linoleic, linolenic. The use of oils in product recipes can have a positive effect on the fatty acid composition.

Prospects for further research are to develop new recipes for organic cookies and to study its nutritional value.

\section{References}

[1] Yue, Q., Xu, X., Hillier, J., Cheng, K., Pan, G. (2017). Mitigating greenhouse gas emissions in agriculture: From farm production to food consumption. Journal of Cleaner Production, 149, 1011-1019. doi: https://doi.org/10.1016/j.jclepro.2017.02.172

[2] Birt, C. A. (2016). Food and Agriculture Policy in Europe. AIMS Public Health, 3 (1), 131-140. doi: https://doi.org/10.3934/ publichealth.2016.1.131

[3] Prutska, O. O., Byelyayeva, N. V. (2012). World experience of organic agriculture state support. Zbirnyk naukovykh prats VNAU. Seriya: Ekonomichni nauky, 2 (1 (56)), 212-218.

[4] Willer, H., Schlatter, B., Travnicek, J., Kemper, L., J. Lernoud (Eds.) (2020). The world of organic agriculture. Statistic\&Emerging Trends 2020. Research Institute of Organic Agriculture FiBL, 337.

[5] Davydovych, O. Ya., Lozova, T. M. (2016). Pechyvo tsukrove z netradytsiynymy vydamy boroshna. Hlebniy i konditerskiy biznes, 7, 26-27.

[6] Obolkina, V., Yemelianova, N., Skrypko, A. (2014). Zdobne pechyvo z vykorystanniam boroshna z proroshchenykh zeren vivsa ta pshenytsi. Prodovolcha industriia APK, 2, 28-32. Available at: http://nbuv.gov.ua/UJRN/Piapk_2014_2_10

[7] Lozova, T., Kovalchuk, H. (2013). Commodityresearch storage new cakes. Herald of LUTE. Technical sciences, 13, 11-13. Available at: http://journals-lute.lviv.ua/index.php/visnyk-tech/article/view/469/442

[8] Tkachenko, A., Guba, L., Basova, Y., Goryachova, E., Syrokhman, I. (2021). Developing organic cookies with improved consumer properties using safety management approaches. Eastern-European Journal of Enterprise Technologies, 2 (11 (110)), 41-49. doi: https://doi.org/10.15587/1729-4061.2021.230123

[9] Zhyhunov, D. O., Voloshenko, O. S., Khorenghy, N. V. (2018). Comparative study of the quality indices of the whole grainw-heat and spelta flour of thedomestic production. Grain Products and Mixed Fodder's, 18 (3), 15-20. doi: https:/doi.org/10.15673/ gpmf.v18i3.1071

[10] Trinidad, P. T., Divinagracia, H. V., Aida, C. M., Faridah, C. A., Angelica, S. M., Modesto, T. C. et. al. (2001). Coconut flour from residue: A good source of dietary fibre. Indian Coconut Journal, XXXII (6), 9-13.

How to cite: Tkachenko, A., Syrokhman, I., Guba, L., Basova, Y., Goryachova, E. (2021). Formation of productivity of sowing peas depending on technology measures of cultivation in the conditions of the western forest-steppe. EUREKA: Life Sciences, 3, 36-40. doi: https://doi.org/10.21303/2504-5695.2021.001882 